\title{
The Health Fitness Level in The Men Athlet Basket Ball in Christian Satya Wacana Salatiga Middle School
}

\author{
Kukuh Pambuka Putra ${ }^{1 \bowtie}$, Andrian Fernandes ${ }^{2}$, Angkit kinasih ${ }^{3}$
}

Program Studi Pendidikan Jasmani Kesehatan dan Rekreasi, Fakultas Kedokteran dan Ilmu, Satya Wacana Salatiga, Indonesia ${ }^{123}$

\section{History Article}

Received 07 November 2018

Approved 25 July 2019

Published 31 July 2019

\section{Keywords}

Fartlek, VO2max, physical fitnes, Basket Ball

\begin{abstract}
Basketball requires a good physical fitness condition, a good physical fitness needs an adequate exercise program, one of the popular exercise program is fartlek method. The purpose of this study is to know the effect of fartlek method that have had done for eight weeks (twice in a week) towards the VO2max of SMP Kristen Satya Wacana's male basketball extracurricular. Based on the previous study about physical fitness, the participants of SMP Kristen Satya Wacana's basketball extracurricular had a poor physical fitness proven by the result of cooper test that shown the VO2max on SMP Kristen Satya Wacana's male basketball extracurricular was $29,19 \mathrm{ml} \square \mathrm{kg}$-1 $\square \mathrm{min}-1$ (very poor). The VO2max was calculated using cooper test. The VO2max's result on this research is $53,4919 \mathrm{ml}-\mathrm{kg}-1-\mathrm{min}-1$, which is very good. T-tests were used to determine the result of pretest and postest, and the result of the vo2max is $26,03111 \pm 7,5 \mathrm{ml} \cdot \mathrm{kg}-1 \cdot \mathrm{min}-1(\mathrm{p}<0,05)$. Based on the result of this research, fartlek could be used to increase the VO2max of basketball male athletes of SMP Kristen Satya Wacana Salatiga.
\end{abstract}

\section{How to Cite}

Putra, K., P. et all. (2019). The Health Fitness Level in The Men Athlet Basket Ball in Christian Satya Wacana Salatiga Middle School. Journal of Physical Education, Health and Sport, 6 (1), 18-22. 


\section{INTRODUCTION}

Physical fitness is a physical condition that allows a person to do a job without feeling tired, and still has a good ability for other jobs (halim, 2012; suharjana \& purwanto, 2008). Physical fitness is influenced by two aspects, namely health and performance, health aspects consist of: heart fitness, lungs, smooth circulation, fat in the body, and flexibility in the joints. Whereas the aspects of performance consist of: slippage, explosive power, speed, coordination and agility (afriwardi, 2010). An athlete must have good physical fitness, because if you have good physical fitness you can support the performance of an athlete to be good.

Satya wacana christian middle school salatiga has activities that are intended to develop students talents and interests, one of which is basketball. Ball games are a sport that is very much recognized by the public. The basketball game is played by two teams, each team consists of 12 players, with players in the field as many as 5 people while in the reserve it contains 7 people, playing this basketball game there are two ways to do it by attacking and defending, the winning team is the team that has the most boal in the ring (butolo, 2013). Basketball games are very interesting to play because basketball games can be played by all teenagers, adults and the elderly. In basketball games a person is required to master the basic techniques of basketball games, fitness, coordination, good endurance. In basketball games there is not often body contact, because there are game rules so that injuries do not easily occur to an athlete (rustanto, 2015).

Basketball games for athletes are required to have good physical fitness, because during training and competition it will not be easy to feel tired and more vulnerable to an athlete who is not susceptible to injury which can interfere with the appearance of an athlete. A basketball athlete must have good physical abilities, because physical abilities are related to the athleters physical fitness. If an athlete has good physical fitness, then during training or competition it is very helpful for the coach to direct the training program and strategies that have been prepared for the players or athletes (Wibowo, 2017). to measure physical fitness, one of them can use endurance test, cardiovascular endurance as stated by VO2max (Putra, 2013). VO2max is the maximum amount of oxygen consumed during intense physical activity and eventually fatigue (Watulingas, Rampengan, \& Polii, 2013). Based on the preliminary study of physical fitness test results with the method of 12 minutes running test or endurance test (cooper test) on male basketball athletes in Satya Wacana Christian
Middle School Salatiga with an average age of 1215 years, the results of $\mathrm{VO} 2 \mathrm{max}$ in average male athletes were found to be $29.19 \mathrm{ml}-\mathrm{kg}-1-\mathrm{min}-1$ (very bad), therefore one of the exercises that can improve physical fitness is fartlek training, which will be given to male basketball athletes at Satya Wacana Christian Middle School Salatiga. Fartlek training is a pioneer of interval training systems where this exercise is carried out on an ongoing basis, carried out in open fields or fields (Foss \& Keteyian, 1998). Fartlek training is carried out in an open field that begins with jogging and short sprints, after which jogging and jogging run at medium speed and so on (Herta, Nurseto, \& Jubaedi, 2016). The purpose of this study is to find out whether the fartlek method can be useful for improving the physical fitness of male basketball athletes at Satya Wacana Christian Middle School Salatiga?.

\section{METHOD}

This research is a pre-experimental research study using the pretest-posttest design. (sudigdo sastroasmoro, 2011).

This study will study the effect of the fartlek training method on vo2max students aged $12-15$ years, the population in this study were 18 male athletes. To find out the pre-test for male basketball athletes in satya wacana christian middle school salatiga, tests will be conducted using the cooper test method. After the pre-test results are known, treatment will be given using the fartlek training method, the training method is as follows,

Fartlek training program

Tuesday

1. 100 meter jogging participant 50 meter sprint of this exercise is carried out continuously for up to 15 minutes

2. Participants jog for 2 minutes and continue by running fast / sprint for 30 seconds by following reps

Friday

1.Participation in a 200 meter sprint and continue with jogging along 100 meters with a specified time of 15 minutes instrumen

The treatment given is fartlek training (speed play). To find out VO2max in men's basketball athletes, Satya Wacana Christian Middle School Salatiga was conducted before and after (pre-test and post-test). VO2max examination was performed using a 12-minute running instrument (cooper test) in the form of a test running around the running track on section 1 for 12 minutes to determine the level of $\mathrm{VO} 2 \mathrm{max}$ in athletes

The procedure for administering fartlek 
training will be given 2 training sessions on Tuesday and Friday. Each training session is conducted sequentially starting from warming up for 20 minutes, after warming up the athlete will do a program of programmed fartlek training, the core training on Monday is Participants running for 15 minutes by jogging 100 meters followed by a 50 meter running sprint carried out with continuous until 10 minutes ends, after which students are given a period of rest for 3 minutes, after resting the students will continue the second program is Participants run by using jogging time for 2 minutes and continue with fast sprint / sprint for 30 seconds and while for Training on Friday will be given an exercise program that will be carried out. The participant runs for 10 minutes with 200 meters running fast / sprint and continues with jogging along 100 meters with the time specified. This fartlek training program will be carried out by students for 1 and a half months. This study uses a pre-test and post-test design which are both carried out with the same procedure. After the pre-test has been done students will run fartlek training for 1 and a half months, after the fartlek training program is run for 1 and a half months a post-test will be carried out to determine whether the student VO2max has changed after doing fartlek training

The data that has been obtained will be described to find out the results of the data, after the data has been described the data obtained will be tested by the normality test using the columnogorov smirnov test to find out whether the data can be proven normal or not. After testing the normality test and the columnogorov smirnov test, the results of the VO2max pre-test and post-test scores will be compared and will be tested using paired-test $\mathrm{T}$ test because to find out if there are differences in the values between before and after treatment and to determine the level of influence of the difference in value (Purwanto \& Irwadi, 2014). Data processing will be processed by means of statistics, processing data from this study will be processed using the help of applications about IBM SPSS statistical analysis and pre-setup data will be processed using Microsoft Excel software / applications.

\section{RESULTS AND DISCUSSION}

Data that has been obtained from the treatment results pre-test and post-test shows that there is a difference in the value of $\mathrm{VO} 2 \mathrm{max}$ which is quite different.

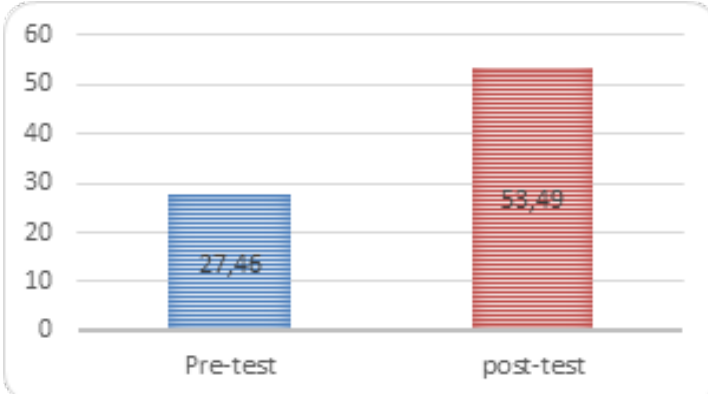

Diagram 1. Changing the Value of VO2max (ml-kg-1-min-1)

Table 1. Description of pre-test statistics and post-test

\begin{tabular}{lcc}
\hline \multicolumn{1}{c}{ Statistik } & Pre-test & Pos-test \\
\hline $\mathrm{N}$ & 18 & 18 \\
Mean & 27,46 & 53,49 \\
Max & 42,37 & 59,83 \\
Min & 15,54 & 47,98 \\
\hline
\end{tabular}

Data from Table 1 the pre-test results showed that the average VO2max value obtained was $27.46 \pm 6 \mathrm{ml} \cdot \mathrm{kg}-1 \cdot \mathrm{min}-1$ while the average $\mathrm{VO} 2 \mathrm{max}$ result in the post-test was $53.49 \pm 3.7$ (ml-kg -1-min-1) the results are formulated using the formula: (distance traveled - 504.9): $44.73 \mathrm{ml}$ $\cdot \mathrm{kg}-1 \cdot \min -1$. Data obtained from the results of the pre-test and post-test, it was seen that there was a difference in the value of $\mathrm{VO} 2 \mathrm{max}$ which increased by 26.03 (ml-kg-1-min-1).

The results of the pre-test and post-test data that have been treated then the data will be tested by the normality test using the columnogorov smirnov test, the purpose of the test is to find out whether the data is normal or not. Based on the results of the pre-test and post-test data after testing the normality test using columnogorov smirnov with sig results of $p=0.2(p>0.05)$, it shows that the value is normal. From the results of columnogorov smirnov test, the value of VO2 max from the pre-test and post-test can be called normal if the value above ( $p>0.05)$, from the results of the data processing data can be continued with different tests using the T test paired (pairedtest).

Table 2. The results of t-test paired with pre-test and post-test scores

\begin{tabular}{lccc}
\hline $\begin{array}{l}\text { Pair } 1 \\
\text { pretest- }\end{array}$ & Mean & $\begin{array}{l}\text { Std. de- } \\
\text { viation }\end{array}$ & $\begin{array}{c}\text { Sig. (2 } \\
\text { tailed) }\end{array}$ \\
postest & 26,03111 & 7,54722 &, 000 \\
\hline
\end{tabular}


The results Table 2 of the pre-test and post-test values that have been tested using paired $\mathrm{t}$ test, it is known that the value of VO2max with an average of $26.03111 \pm 7.5 \mathrm{ml} \cdot \mathrm{kg}-1 \cdot \mathrm{mi}-1$ (p $<0.000)$. From the results of the paired $t$ test that the values of the pre-test and post-test showed a difference, then from the results of the paired $t$ test there was a significant increase from the pretest and post-test. Based on the results of data analysis, after being treated by using the method of fartlek training (speed play) that there were significant differences from the pre-test and posttest.

Based on the results of this study it was found that the method of fartlek training can increase endurance (VO2max). there are several factors that influence the increase in VO2max, one of which is hemoglobin. Hemoglobin is a molecule consisting of two parts, namely heme and globin, which is the main content of ethrosite which has millions of molecules in hemoglobin. Hemoglobin is very important in training because hemoglobin transports oxygen from the lungs to the muscles that work (R, S. Debbian \& Rismayanti, 2016).

There is a study proving that the method of fartlek training can increase VO2max in adults (Handayani, 2018). The method of fartlek training can increase one's endurance, high endurance can support athletes' physical performance (Ahmed \& Hashem, 2011) and fartlek training methods can also increase resting and breathing pulse pressure (Begum \& Hussain, 2013). Based on the results of a study the method of fartlek training can be used as a method for restoring athlete performance so that the development of an athlete's performance can be maximized (Kurz, Berg, Latin, \& Degraw, 2000). besides the fartlek method there are many methods for increasing endurance, including: high intensity interval training, cross country, circuit training, and other training methods. An exercise program that can increase endurance, such as exercises that use the high intensity interval training training method has been proven that the training method can increase athletes VO2max (Kukuh, Ardha, Kinasih, \& Aji Setiyo, 2017). In addition to the trainig high intensity interval method, the circuit training method also influences physical fitness, because using the sircuit training method can train the whole body simultaneously, where the implementation of this training program consists of several circuits which are carried out by changing the time limit (Suminah, 2015). Of the various types of training methods that can improve physical fitness are not much different if compared with the method of fartlek training because it shows the same significant effect. The method of fartek training has advantages and disadvantages, the advantages of fartlek for children after this exercise capacity is not too heavy and easy to teach while the lack of fartlek in this study is because fartlek training is done simultaneously so that when sprinting there is a jumble and narrower running distance. This study also has limitations, these limitations are difficult to regulate the time for training, the weather that does not support, and the physical condition of the children, so that the exercise is not optimal. Suggestions in using the fartlek training method are, the advice of this research as a researcher must require commitment from children or athletes and most importantly in preparing a varied and correct training program, so that children do not feel quickly bored and avoid injury easily.

\section{CONCLUSION}

The method of fartlek training can improve the physical fitness of male basketball athletes at the Satya Wacana Christian Middle School in Salatiga, and show that there is a significant change in VO2max in basketball athletes at Satya Wacana Christian Middle School Salatiga.

\section{REFERENCES}

Afriwardi. (2010). Ilmu Kedokteran Olahraga. (F. Dany, Ed.). Jakarta: Buku kedokteran EGC.

Ahmed, Z. A., \& Hashem, D. M. S. (2011). Effect of Using Fartlek Exercises on Some Physical and Physiological Variables of Football and Volleyball Players. World Journal of Sport Sciences, 5(4), 226-229.

Begum, A., \& Hussain, I. (2013). Effect of fartlek training on selected physical and physiological variables of inter district women athletes. International Journal Of Creative Research Thoughts, 1(3), 4.

Butolo, A. (2013). Meningkatakan kemampuan tembakan bebas bola basket melalui pendekatan bermain pada siswa kelas VI SD Kayutanyo kecamatan liwuk timur. Tadulako Physical, Health and Recreation Ejournal, 1(1), 3.

Foss, M. 1., \& Keteyian, S. J. (1998). fox's physiological basis for exercise and sport. (J. Watters, Ed.) (6th ed.). United States: edward e. bartell.

Halim, S. (2012). Manfaat tes kebugaran atau tes kesegaran jasmani untuk menilai tingkat 
Kukuh Pambuka Putra, et all. / Journal of Physical Education, Health and Sport 6 (1) (2019) 18-22

kebugaran. Journal Kedokteran Meditek, 18(47).

Handayani, aini nur. (2018). Pengaruh fartlek training terhadap VO2max pada mahasiswa ever weight. Unisa, 11.

Herta, I. ketut, Nurseto, F., \& Jubaedi, A. (2016). Pengaruh fartlek dan joging terhadap peningkatan vo2max tim sepak bola sman 1 kota gajah. Jurnal Penjaskesrek, 4(4), 8.

Kukuh, P. P., Ardha, M. arif Al, Kinasih, A., \& Aji Setiyo, R. (2017). Korelasi perubahan nilai Vo2max, eritrosit, hemoglobin dan hematokrit setelah latihan high intensity interval training. Jurnal Keolahragaan, 5(2), 161-170. Retrieved from http://journal.uny.ac.id/index.php/jolahraga

Kurz, j max, Berg, K., Latin, R., \& Degraw, W. (2000). The relationship of training methods in ncaa division i cross-country runners and 10,000-meter performance. Journal of Stebght and Conditioning, 14(2), 200.

Purwanto, B., \& Irwadi, I. (2014). Panduan praktis belajar statistik. Surabaya: PT revka petra media.

Putra, P. K. (2013). pengaruh program pelatihan fisik militer terhadap peningkatan VO2 max siswa pendidikan pertama tamtama tentara nasional indonesia angkatan laut (studi dipuslatdikarsmil kobangdikal sura- baya). Jurnal Keolahragaan, 1(1), 2.

R, S. Debbian, A., \& Rismayanti, C. (2016). Profil tingkat volume oksigen maksimal (VO2max) dan kadar hemoglobin pada atlet yongmoodo akademi militer magelang. Jurnal Olahraga Prestasi, 12, 23-24.

Rustanto, H. (2015). Hubungan antara tinngi badan dan kelincahan tubuh terhadap hasil dribble bola bola pada permainan basket. Jurnal Pendidikan Olahraga, 4(2), 145146.

Sudigdo Sastroasmoro. (2011). Dasar- dasar metodologi penelitian klinis (4th ed.). Jakarta: CV Sugeng Seto.

Suharjana, F., \& Purwanto, H. (2008). Kebugaran jasmani mahasiswa d II PGSD Penjas FIK. Jurnal Pendidikan Jasmani Indonesia, 5(2), 45-51.

Suminah. (2015). Pengaruh circuit training terhadap kebugaran jasmani siswa kelas IV putra sd negeri percobaan 3 pakem sleman. Universitas Negeri Yogyakarta, 65.

Watulingas, I., Rampengan, J. j. v., \& Polii, H. (2013). pengaruh latihan fisik aerobik terhadap vo2max pada mahasiswa dengan berat badan lebih (overweight). E-Biomedik, 1(2), 2.

Wibowo, antonius tri. (2017). Gaya hidup, kebugaran jasmani, dan konsentrasi atlet bola basket tim Satya Wacana Salatiga menghadapi Indonesia baske $t$ ball league (IBL) 2017. Jurnal Sportif, 2(2), 23. 